\title{
Relationship among grazing management, growing degree- days, and morphological development for native grasses on the Northern Great Plains
}

\author{
A.B. FRANK AND L. HOFMANN
}

\section{Abstract}

Air temperature or growing degree-days (GDD) are known to influence morphological development of grass, but the effects of grazing history on grass morphological development has not been established. Morphological development of 5 species located on moderately and heavily grazed mixed prairie sites near Mandan, North Dakota, was determined 3 times per week from beginning of growth in spring to heading. The species were western wheatgrass [Pascopyrum smithii Rydb. (Löve)], blue grama [Bouteloua gractlis (H.B.K.) Lag. ex Griffiths], needleandthread (Stipa comata Trin. and Rupr.), green needlegrass (S. viridula Trin.), and prairie junegrass [Koeleria pyramidata (Lam.) Beauv.]. Regression analysis of growth stage with GDD was linear and statistically significant for prairie junegrass $\left(R^{2}=0.62\right)$, green needlegrass $\left(R^{2}=0.96\right)$, and needleandthread $\left(R^{2}=0.95\right)$, and nonlinear for blue grama $\left(R^{2}=0.95\right)$ and western wheatgrass $\left(R^{2}=0.97\right)$. Prior grazing management had little effect on this relationship. The number of leaves and accumulated GDD required to produce those leaves varied by each species: prairie junegrass (4 leaves, 520 GDD), needleandthread (4 leaves, 640 GDD), green needlegrass (4 leaves, 800 GDD), blue grama (5 leaves, 1,300 GDD), and western wheatgrass (6 leaves, 1,450 GDD). Based on the species and conditions of this study, plant growth stage can be predicted from accumulated GDD and used for predicting graxing readiness and in development of forage growth models.

Key Words: growing degree-days, growth rate, forage, Pascopyrum smithii, Bouteloua gracilis, Stipa comata, Stipa viridula, Koeleria pyramidata

Early season morphological development and growth of forage grasses is important to gaining maximum forage productivity during the grazing period. Rate of morphological development of grasses grown in the Northern Great Plains is mostly controlled by air temperature, whereas quantity of forage produced is more a function of available soil water and nutrients. The effects of air temperature on plant morphological development has been evaluated for numerous crops including corn (Zea mays L.) (Bunting 1976), spring wheat (Triticum aestivum L.) (Bauer et al. 1984), and forage grasses (Frank et al. 1985) through application of the growing degree-days (GDD) concept. The most common use of GDD has been to determine days to maturity in vegetables and crops grown for seed products. Application of GDD to development of forage crops is limited (Frank et al. 1985), especially effects of past management practices on subsequent plant development.

Wang (1960) reviewed 230 years of literature dealing with the GDD concept and morphological development of various crop plants and suggested changes to improve utility of the concept. Numerous reports (Rogler and Haas 1947, Smika et al. 1965, and Sneva 1977) provide information on effects of management, water,

\footnotetext{
Authors are plant physiologist and agronomist, USDA-ARS, P.O. Box 459, Mandan, North Dakota 58554.

This article is a contribution from USDA, Agricultural Research Service, Mandan, North Dakota.

Manuscript accepted 9 November 1988.
}

and nutrients on quantity of forage produced, but the morphological development of the plant often is not evaluated. Laude (1971) reviewed effects of adverse hot and cold temperature on grass growth and emphasized the importance of evaluating temperature effects throughout the entire life cycle of the plant. Regression analysis has been used to show that a strong linear relationship exists between morphological development and accumulated heat units or GDD for such crops as spring wheat (Bauer et al. 1984, Davidson and Campbell 1983); corn (Cross and Zuber 1972); and for seeded forage grasses like crested wheatgrass [Agropyron desertorum (Fisch.) Schult.]; intermediate wheatgrass [Thinopyrum intermedium (Host) Barkw. and D.R. Dewey subsp. intermedium]; western wheatgrass [Pascopyrum smithii Rydb. (Löve)]; and reed canarygrass (Phalaris arundinacea L.) (Frank et al. 1985).

Determining the effects of prior management practices on the relationship between plant development and GDD should be beneficial in application of the concept of grazing management, especially in determining grazing readiness, and in refinement of growth and management simulation models. The objective of this study was to determine the effect of air temperature (accumulated GDD) on morphological development of western wheatgrass, blue grama [Bouteloua gracilis (H.B.K.) Lag. ex Griffiths], prairie junegrass [Koeleria pyramidata (Lam.) Beauv.], needleandthread (Stipa comata Trin. and Rupr.), and green needlegrass ( $S$. viridula Trin.) in pastures with 2 different grazing histories.

\section{Materials and Methods}

The study was conducted on both a moderately and heavily grazed native mixed prairie site on a Williams loam (fine-loamy mixed Typic Argiboroll) near Mandan, ND(46.46 N, and $\left.100^{\circ} 50^{\circ} \mathrm{W}\right)$ during 1986 and 1987. The April through September rainfall was $476 \mathrm{~mm}$ in 1986 and $386 \mathrm{~mm}$ in 1987. The moderately grazed pasture was a 13-ha typical Northern Great Plains mixed prairie site that had been grazed with yearling steers at 1 steer $2.6 \mathrm{ha}^{-1}$ from about mid-May to October for the past 70 years. Grazing was excluded from the sampling areas within the pastures each year. Primary cover composition, as determined at the end of August 1984 by first hits using the point frame technique, was $13 \%$ blue grama, $10 \%$ threadleaf sedge (Carex filifolia Nutt.), $9 \%$ yellow sedge (Carex pennsylvanica Lam.), 5\% needleandthread, $4 \%$ western wheatgrass, $4 \%$ prairie junegrass, and $44 \%$ litter. The heavily grazed native pasture was also a 2.8 ha typical mixed prairie site that had been purposely overgrazed during the same 70 -year period at the intensity of 1 steer $0.9 \mathrm{ha}^{-1}$. Primary cover composition of the heavily grazed pasture was $34 \%$ blue grama, $35 \%$ litter, and $22 \%$ bare ground. Herbage samples that included only standing green material were collected weekly from small ungrazed fenced sections within each pasture beginning on 22 April and ending on 21 October 1986 and beginning on 28 April and ending on 15 September 1987. Herbage was hand clipped from $25 \times 100$ $\mathrm{cm}$ areas from 4 sites within each pasture and year at the soil surface, oven dried at $70^{\circ} \mathrm{C}$, and weighed for total dry matter. The 
herbage yield data were analyzed using analysis of variance procedures. Plant morphological development was determined on reproductive stems of western wheatgrass, blue grama, needleandthread, green needlegrass, and prairie junegrass at 2- to 3-day intervals during 1986 and 1987 using the Haun (Haun 1973) growth stage scale (HGS). Plants were identified and marked in the field in autumn 1985 and 1986 to facilitate scoring for morphological development in the early growth stages during 1986 and 1987 , respectively. Scoring was started 7 April 1986 and 13 April 1987, and continued through flag leaf development. Nine plants of each species were scored in 1986 and 12 plants in 1987. Daily minimum and maximum air temperature was measured using a portable data acquisition system at 1-hour intervals with shielded copper constantan thermocouples at 1 meter above the soil surface. Measurements were made at the moderately grazed site which was about $600 \mathrm{~m}$ from the heavily grazed site. Growing-degree days (GDD) were calculated from the air temperature data as GDD = maximum daily temperature + minimum daily temperature/2-base temperature and were accumulated starting on 31 March 1986 and 1 April 1987. A base temperature of $0^{\circ} \mathrm{C}$ was used for all species. The starting date for accumulation of GDD was selected as the first day after $15 \mathrm{March}$ that the daily average minimum plus maximum air temperature exceeded $0^{\circ} \mathrm{C}$ for 5 consecutive days. The data were analyzed using regression analysis to define the relationship between HGS and accumulated GDD.

Six access tubes were placed at each site adjacent to the selected plants and soil-water content was measured weekly at $0.3-\mathrm{m}$ intervals to $1.2-\mathrm{m}$ depth beginning at $0.1 \mathrm{~m}$ below the surface using a neutron moisture meter. Soil water content at $1.5 \mathrm{MPa}$ matrix potential averaged $40 \mathrm{~mm} 0.3 \mathrm{~m}^{-1}$ soil depth increment to $1.2 \mathrm{~m}$ soil depth. Available soil water was determined to a depth of $1.2 \mathrm{~m}$ by summation of total soil water minus $40 \mathrm{~mm}$ for each $0.3 \mathrm{~m}$ soil depth increment. Precipitation was measured using a recording rain gage located at the moderately grazed site.

\section{Results and Discussion}

The accumulated GDD were greater in 1987 than in 1986 (Fig. 1). This difference occurred early in 1987 as the result of above

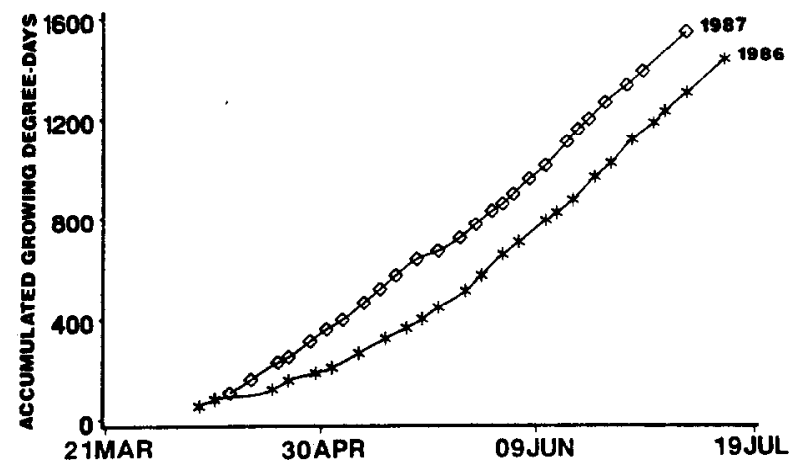

Fig. 1. Accumulated growing degree-days received at Mandan, North Dakota in 1986 and 1987.

average temperatures and resulted in 209 and 359 GDD by 2 May in 1986 and 1987, respectively. Growing conditions were favorable for both years in that precipitation received from April to September of 476 and $386 \mathrm{~mm}$ in 1986 and 1987 , respectively, was above the long term average of $319 \mathrm{~mm}$. This resulted in favorable available soil water throughout most of the growing season except for the period around 1 July during both years. Available soil water during the forage growing season was nearly the same for both the heavily and moderately grazed pastures for both years (Fig. 2). Total dry matter yield differed between the heavily and moderately grazed
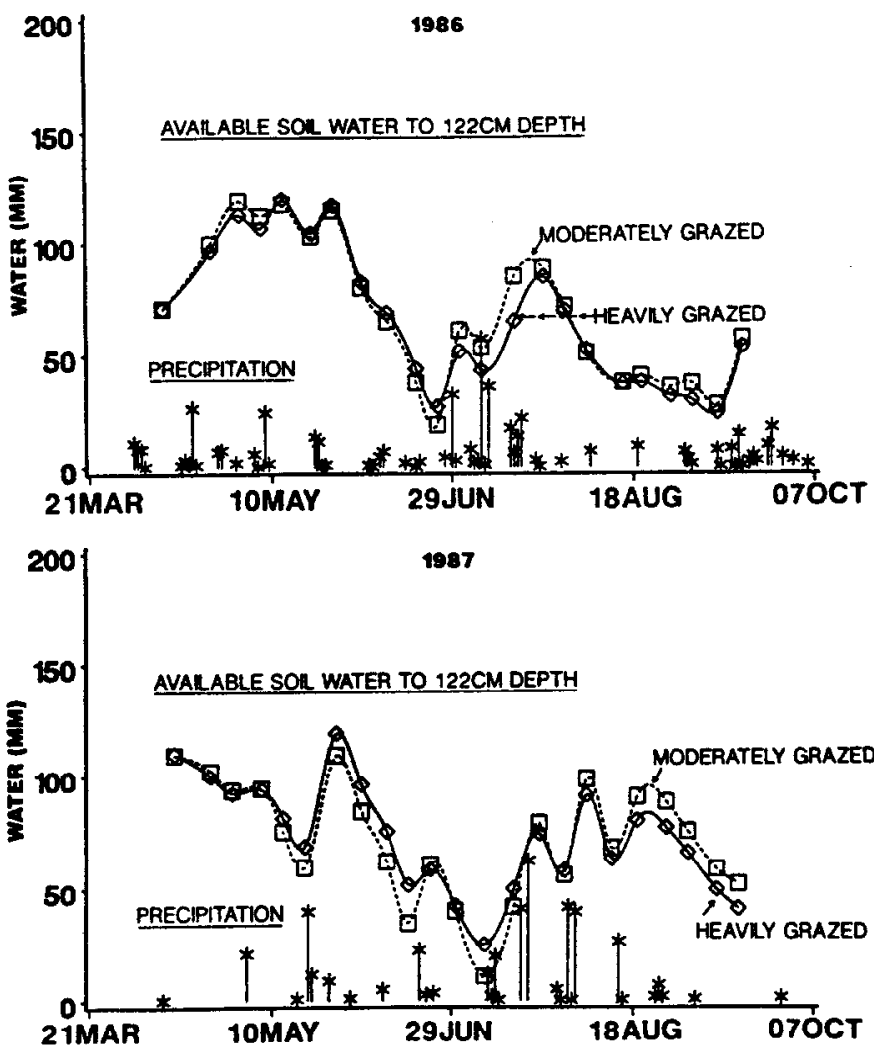

Fig. 2. Available soil water content and precipitation for moderately and heavily grazed pastures in 1986 and 1987.

pastures ( $P>\mathrm{F} 0.001$ ) but the production was similar among years $(P>\mathrm{F} 0.22$ ) for each grazing treatment (Fig. 3). This suggests that the difference in dry matter yield was due to species composition and prior grazing management and not precipitation or soil water content.

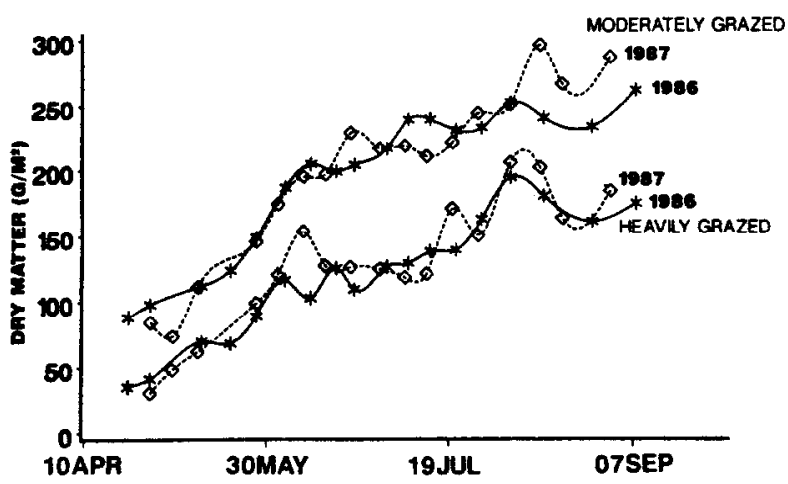

Fig. 3. Dry matter forage production for the moderately and heavily grazed pastures in 1986 and 1987 . The $P>F$ from the analysis of variance was 0.001 for pastures and 0.22 for years.

The progression of plant development as measured by the HGS was linearly related to accumulated GDD for prairie junegrass (Fig. 4), green needlegrass (Fig. 5), and needleandthread (Fig. 6). The regression equation of HGS versus GDD for prairie junegrass produced a greater intercept in 1986 compared to 1987 . This produced a lower combined coefficient of determination $\left(R^{2}=0.62\right)$ for analysis based on data for both years. In 1986, the majority of tagged prairic junegrass plants produced 4 leaves, but a few plants produced 5 leaves. In 1987, plants only produced 3 and 4 leaves. 


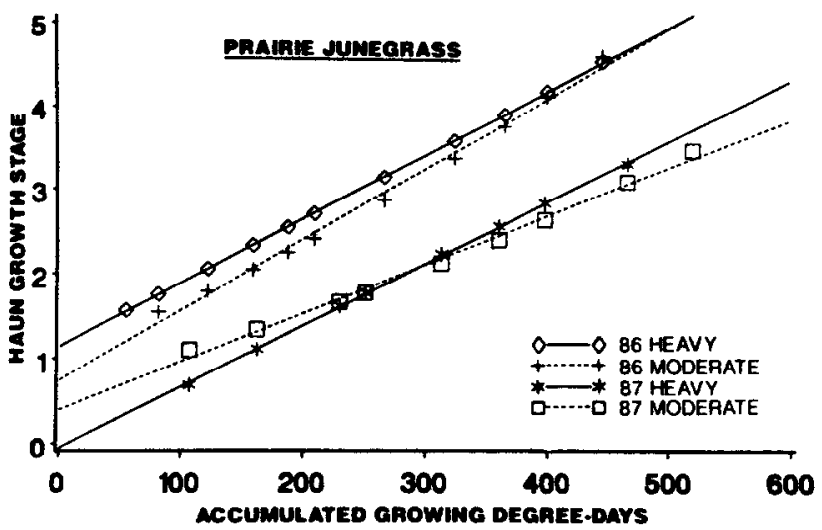

Fig. 4. Relationship between Haun growth stage and accumulated GDD for prairie junegrass. Regression equations were as follows: Heavy 86: Hawn $=1.145+0.0075(G D D), \mathrm{R}^{2}=0.99$ Heavy 87: Hawn $=-0.045+0.0072(G D D), R^{2}=0.98$ Moderate 86: Hawn $=0.752+0.0083(G D D), \mathrm{R}^{2}=0.99$ Moderate 87:Haun $=0.404+0.0056(G D D), \mathrm{R}^{2}=0.99$ Combined Regression:Haun $=0.887+0.0061(G D D), \mathbf{R}^{2}=0.62$

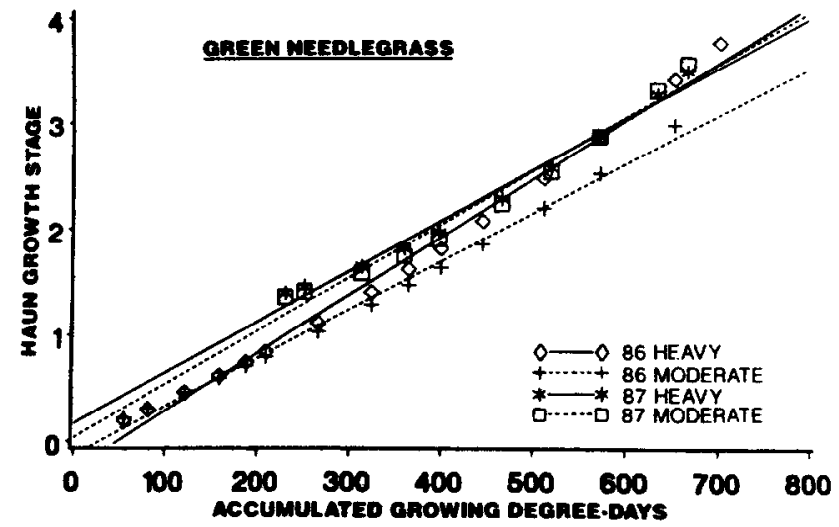

Fic. S. Relationship between Haun growth stages and accumulated GDD for green needlegrass. Regression equations were as follows: Heavy 86:Hawn $=-0.261+0.0055(G D D), \mathbf{R}^{2}=0.99$ Heavy 87:Haun $=0.167+0.0048(G D D), R^{2}=0.97$ Moderate 86:Haun $=-0.127+0.0046(G D D), \mathbf{R}^{2}=0.99$ Moderate 87:Haun $=0.036+0.0050(G D D), \mathrm{R}^{2}=0.95$ Combined Regression: Haun $=-0.172+0.0052(G D D), \mathrm{R}^{2}=0.96$

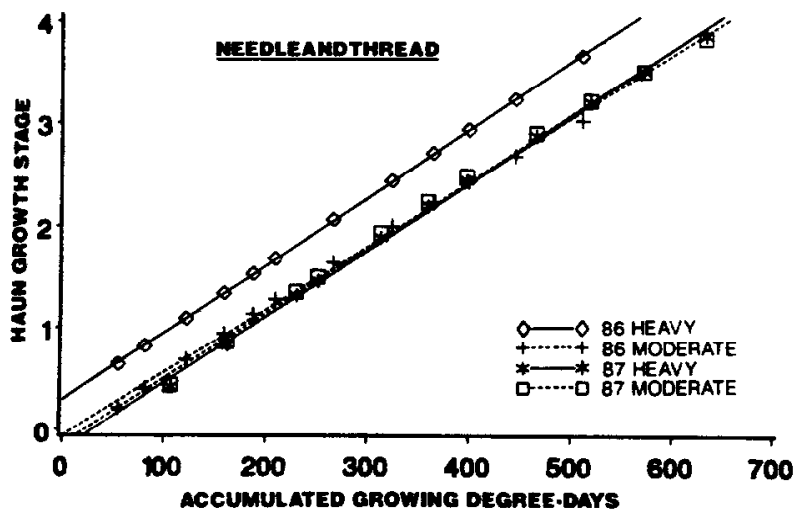

Fig. 6. Relationship between Haun growth stage and accumulated GDD for needleandthread. Regression equations were as follows: Heavy 86:Hawn $=0.289+0.0066(G D D), \mathrm{R}^{2}=0.99$ Heavy 87:Hawn $=-0.194+0.0065(G D D), R^{2}=0.99$ Moderate 86:Heun $=-0.061+0.0062(G D D), \mathrm{R}^{2}=0.99$ Moderate 87:Haun $=-0.141+0.0064(G D D), R^{2}=0.99$ Combined Regression: Haun $=0.061+0.0062(G D D), R^{2}=0.95$
These data are interpreted as showing that more GDD were required to produce a leaf in 1987 than in 1986. Since prairie junegrass is a very early developing species, the above-average GDD accumulated in 1987 may have adversely affected the rate of development. However, both the heavy and moderate grazed pastures responded similarly within each year.

The 2 Stipa species each produced 4 leaves (Figs. 5 and 6). The relationship between GDD and HGS was linear for green needlegrass $\left(R^{2}=0.96\right)$ and needleandthread $\left(R^{2}=0.95\right)$. The relationship between morphological development and GDD was similar during each year except for needleandthread when plants in the heavily grazed pasture required about 80 fewer GDD to produce the first leaf in 1986 compared to the moderately grazed in both years and the heavily grazed site in 1987 . This difference was rather constant through development of all 4 leaves for needlegrass. Green needlegrass developed slightly slower, requiring about 800 GDD to produce 4 leaves, than needleandthread which required only $640 \mathrm{GDD}$ to produce 4 leaves.

The relationship between GDD and HGS for western wheatgrass was nonlinear especially after HGS of about 3.5 (Fig. 7). The coefficient of determination, $R^{2}=0.97$, indicates a very strong morphological development response to GDD. A total of 6 leaves were

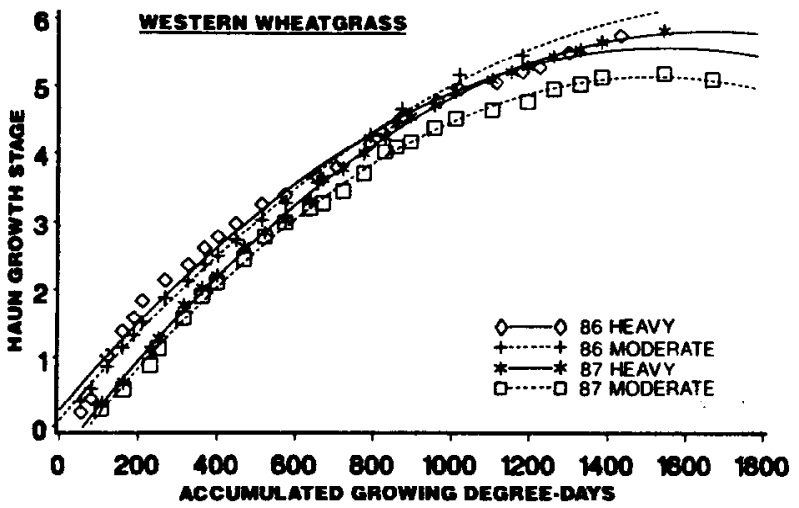

Fig. 7. Relationship between Haun growth stage and accumulated GDD for western wheatgrass. Regression equations were as follows: Heavy 86: Hawn $=0.234+0.0068(G D D)-0.0000022\left(G D D^{2}\right), \mathbf{R}^{2}=0.99$ Heavy 87: Hawn $=-0.455+0.0075(G D D)-0.0000023\left(G D D^{2}\right), \mathrm{R}^{2}=0.99$ Moderate 86: Haun $=0.090+0.0068(G D D)-0.0000019\left(G D D^{2}\right), R^{2}=0.99$ Moderate 87: Hawn $=-0.544+0.0074(G D D)-0.0000024\left(G D D^{2}\right), \mathrm{R}^{2}=0.99$ Combined Regression: Haun $=-0.083+0.0070(G D D)-0.0000022\left(G D D^{2}\right)$, $\mathbf{R}^{2}=0.97$

produced by western wheatgrass plants in both pastures. Previous grazing history effects were not apparent either year. A total of about 1,450 GDD were required to produce the 6 leaves in western wheatgrass. Blue grama also had a nonlinear response between HGS and GDD $\left(R^{2}=0.95\right)$ similar to that of western wheatgrass (Fig. 8). Blue grama produced 5 leaves after about 1,300 GDD were accumulated. However, blue grama is a warm-season species and did not exhibit much growth until about 100 to 125 GDD had accumulated. Grazing effects did not influence the relationship between HGS and accumulated GDD.

When to start accumulating GDD is a difficulty in using GDD to predict plant development. Frank et al. (1985) used criteria similar to that used in this study for determining starting dates for accumulation of GDD in seeded pure grass stands. The grass species evaluated in this study are all perennials that were located in established pastures and growing in competition with other species. The procedure used to select the date for starting accumulation of GDD appears to be satisfactory for the cool-season grasses, but not for blue grama, a warm-season grass species. This was evidenced since the regression analysis produced intercepts that were near zero accumulated GDD for the cool-season species, but 


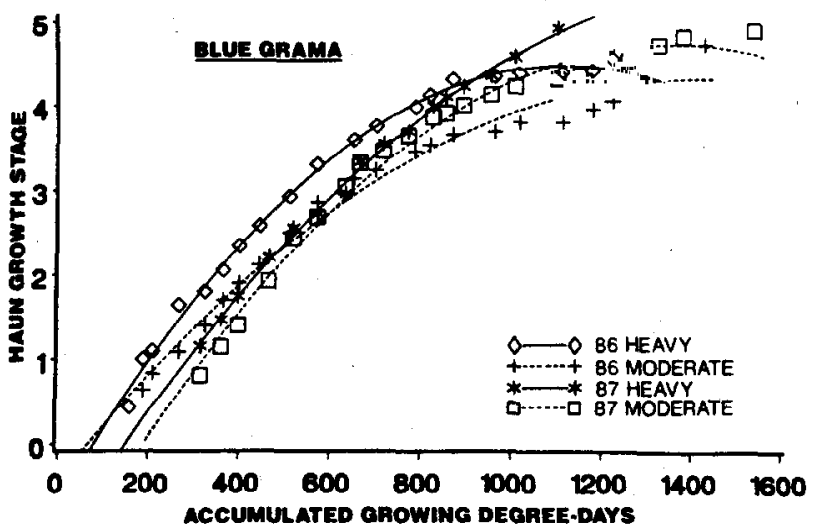

Fig. 8. Relationship between Haun growth stage and accumulated GDD for blue grama. Regression equations were as follows:

Heavy 86: Haun $=-0.704+0.0092(G D D)-0.0000041\left(G D D^{2}\right), R^{2}=0.99$

Heavy 87:Hatn $=-1.208+0.0084(G D D)-0.0000027\left(G D D^{2}\right), \mathrm{R}^{2}=0.99$

Moderate 86: Haun $=-0.431+0.0067(G D D)-0.0000024\left(G D D^{2}\right), \mathrm{R}^{2}=0.98$

Moderate 87: Haun $=-1.654+0.0094(G D D)-0.0000034\left(G D D^{2}\right), \mathrm{R}^{2}=0.98$

Combined Regression:Haun $=-0.699+0.0080(G D D)-0.0000029\left(G D D^{2}\right)$, $\mathbf{R}^{2}=0.95$

about 100 to 125 GDD for blue grama. Accumulated GDD to coincide with initiation of growth for blue grama were 121 and 128 by 21 April 1986 and 15 April 1987, respectively.

Comparisons among species for total accumulated GDD needed to produce the full complement of leaves on the main stem during the growing season varied from 520 for prairie junegrass to 1,450 for western wheatgrass. These data support the field observations which showed that prairie junegrass is one of the earlier species to produce a head compared to western wheatgrass, which produced few heads and at a much later date in the summer. The GDD required for western wheatgrass to produce all 6 leaves in this study $(1,450 \mathrm{GDD})$ were greater than the $778 \mathrm{GDD}$ required by western wheatgrass when grown in pure stands (Frank et al. 1985). The reasons for this difference cannot be determined from this study, but may have been related to the greater competition among plants present in the native sites compared to the pure seeded stands, which slowed development and resulted in a nonlinear response to GDD after a HGS of 3.5.
In spring wheat, Bauer et al. (1984) has shown that morphological development is strongly related to GDD and that GDD can be used as a means of determining when to apply pesticides and fertilizer to the crop. The results of this study also show a strong relationship between HGS and GDD. These results should have practical application in development of growth models, for determining turn out dates for grazing animals, and for making management decisions. The fact that air temperature used as GDD was the primary factor affecting plant development and that prior grazing management, or years had almost no influence on plant development strengthens the possibility of using accumulated GDD for management decisions. Although this report shows that air temperature is the primary driving force controlling morphological development, much research has been reported which shows total forage dry matter produced to be a function of water, soil nutrients, and management factors.

\section{Literature Cited}

Bauer, A., A.B. Frank, and A.L. Black. 1984. Estimation of spring wheat leaf growth rates and anthesis from air temperature. Agron. J. 76:829-835. Bunting, E.S. 1976. Accumulated temperature and maize development in England. J. Agr. Sci. 87:577-583.

Cross, H.F., and M.S. Zuber. 1972. Prediction of flowering dates in maize based on different methods of estimating thermal units. Agron. J. 64:351-355.

Davidson, H.R., and C.A. Campbell. 1983. The effect of temperature, moisture, and nitrogen on the rate of development of spring wheat as measured by degree days. Can. J. Plant Sci. 63:833-846.

Frank, A.B., J.D. Berdahl, and R.E. Barker. 1985. Morphological development and water use in clonal lines of four forage grasses. Crop Sci. 25:339-344.

Haun, J.R. 1973. Visual quantification of wheat development. Agron. J. 65:116-119.

Laude, H.M. 1971. Effect of temperature on morphogenesis. p. 25-33. In: Plant morphogenesis as the basis for scientific management of range resources. Proc. Workshop of US-Aust. Rangelands Panel., Misc. Pub. 1271. USDA-ARS.

Rogler, G.A., and H.J. Haas. 1947. Range production as related to soil moisture and precipitation on the northern Great Plains. Agron. J. 39:378-389.

Smika, D.E., H.J. Haas, and J.F. Power. 1965. Effects of moisture and nitrogen fertilizer on growth and water use by native grass. Agron. J. $57: 483-486$.

Sneva, F.A. 1977. Correlation of precipitation and temperature with spring, regrowth, and mature crested wheatgrass yields. J. Range Manage. 30:270-275.

Wang, J.Y. 1960. A critique of the heat unit approach to plant response studies. Ecology 41:785-790. 